\title{
The US Educational Response to the COVID-19 Pandemic
}

\author{
Nathan Storey, Robert E. Slavin \\ Johns Hopkins University, Baltimore, MD 21286, USA
}

\begin{abstract}
This paper examines the United States federal and state educational responses to the spread of the COVID-19 pandemic, as well as states' plans for reopening schools. The virus entered the United States in January 2020. As the virus spread, most school districts began to close in March. At the end of June, the United States has experienced the highest number of cases and deaths due to COVID-19 in the world, and infection rates appear to be rising once again. Given the great physical and socioeconomic diversity of the United States, the federal and state response to COVID-19 and plans to reopen schools in the autumn have emphasized flexibility and adaptation. However, the implementation of remote (online) learning has highlighted and exacerbated long-standing racial and economic inequalities in US society related to technology access, school engagement, and school-parent relationships. These inequalities may be exacerbated as schools attempt to reopen and students continue to face inconsistent access to learning, learning loss during the spring semester and summer, and COVID-19 spread among the most atrisk population groups. Further research and practical interventions, such as tutoring, should be implemented to address educational equality issues and improve access, whether to in-person or remote instruction.
\end{abstract}

Best Evid Chin Edu 2020; 5(2):617-633.

Doi: 10.15354/bece.20.or027.

How to Cite: Storey, N., Slavin, R.E. (2020) The US educational response to the COVID-19 pandemic. Best Evid Chin Edu, 5(2):617-633.

Keywords: COVID-19; Remote Learning; School Closure; Educational Responses; Online Schooling; Distance Learning; School Reopening.

\footnotetext{
About the Author: Nathan Storey, School of Education, Johns Hopkins University, 300 East Joppa Road 5th fl., Baltimore, MD 21286, USA. Email: nstorey1@jhu.edu

Correspondence to: Robert E. Slavin, Professor, School of Education, Johns Hopkins University, 300 East Joppa Road 5th fl., Baltimore, MD 21286, USA. Email: rslavin@ SuccessForAll.org. 
$\mathrm{I}$ $\mathrm{N}$ the 2020 pandemic, the United States has had the largest number of COVID-19 cases and deaths of any country. Its responses to the health crisis have been fragmented and uncertain. The same fragmentation and uncertainty have prevailed in the US education system, and as of this writing (June 2020), the policies and outcomes of US schools combating COVID-19 are not yet known. The educational response in the United States has emphasized a reliance on flexibility, adaptation, and local decision-making, for both better and worse. This paper will examine the US response to the coronavirus outbreak, focusing on the different approaches taken by different states and school districts, the challenges encountered in closing schools and shifting to remote (online) or distance learning, and prospects for reopening school systems in the Fall 2020. As will be seen, the transition to remote learning was often inconsistent and revealed or exacerbated existing inequalities in US society, especially those related to socioeconomic status and race. These inequalities are likely to be further intensified should the remote learning system continue in place under the conditions that existed in the spring or without large-scale, effective action taken to address COVID-19-related learning loss.

\section{Onset of US Pandemic}

The first identified coronavirus cases in the United States were reported in mid-January 2020, though some speculate the virus entered the United States as early as December 2019, and began circulating in northern California and Washington State, before spreading to other states (Baker, 2020). At the end of January, the US Department of Health and Human Services (HHS) declared a public health emergency, introducing quarantines for US citizens traveling from China and denying entry to non-US citizens who had been to China. Washington State reported the first US death due to coronavirus on February 29, and the virus had been reported in over half of all US states by the middle of March. By the end of March, US states reported over 3,000 deaths and 164,500 confirmed cases. The US federal government passed the Coronavirus Aid, Relief and Economic Security (CARES) Act on March 27, 2020, including support for K-12 and higher education institutions in the form of formula grants to be distributed to states based on their shares of Title I-A funds, to be used for response activities and long-term closure planning and coordination and educational technology purchases, as well as a portion of the Governor's Education Relief Fund, a discretionary sum to be used for emergency support grants for childcare, K-12, and higher education (Reid, 2020). The intention of the bill was to enable flexibility in addressing the specific educational needs each state faced. In addition, the act included $\$ 18.5$ billion for the Supplemental Nutrition Assistance Program (SNAP), supporting child nutrition (Jordan, 2020). One month later, the US had reported 60,966 total deaths and over 1 million confirmed cases, which nearly doubled again by the end of May, when the US reported 103,781 deaths and 1.77 million cases (Ritchie, et al., 2020). As of July 1, 2020, there have been 2.5 million cases and 125,000 deaths, and both numbers continue to accelerate. While the federal government passed some measures and recommended social distancing actions, the more substantive responses to the pandemic have occurred at the state level. 


\section{State and Local Response to COVID-19}

Since no cure or vaccine existed, the main public health response to the pandemic was social distancing, which entailed the closures of most venues in which people gather. This included schools. By the time the CARES Act was signed into law in late March, US states and territories had been forced to take action on their own to determine when and how to close schools and to support teachers and students transition to remote learning. School superintendents petitioned the federal government and the Centers for Disease Control and Prevention (CDC) for guidance on how to respond to the pandemic in February (Binkley, 2020), but the first states did not begin mandating the closures of in-person schooling until mid-March, initially on a two-three week basis, though individual school districts and schools did close earlier than that as students and faculty began testing positive for the disease (Forgie, 2020). By the end of March, all 50 states had announced mandatory or recommended closures of public schools, and most required remote learning in place of in-person classes. Some states, such as Kansas, Virginia, and Oklahoma, decided that schools would not reopen for the remainder of the school year, but other states, including New York, Maryland, and New Jersey, put off that decision until April or early May. Though most states ordered schools to be closed, seven states (California, Idaho, Tennessee, Florida, South Dakota, Maine, and Kentucky) merely recommended schools be closed, allowing district variations in response to the virus, and by May, some counties in Colorado, Wyoming, and Montana (Meltzer, 2020) had begun to reopen in a limited capacity and in smaller, less-populated areas (Map, 2020; Kirsch, 2020). As it became clear that schools would have to remain closed beyond the initial two-week closure, districts began petitioning the federal government for waivers on the required number of school days and hours in a year (Jones \& Pflaum, 2020) and on completion of standardized testing. At least one state, Georgia, petitioned the Department of Education for approval to suspend standardized testing for the 20202021 school year as well (Strauss, 2020). While the school schedule and standardized assessments are determined by states and school districts, receipt of federal funds is tied to completion of these requirements under the basic US education law, the Every Student Succeeds Act (ESSA). With the closing of school campuses for all levels, schools began the process of creating remote learning curricula, materials, and policies and procedures on short notice.

\section{Online Learning Provision and School Services}

The short period between the decision to close schools and the initiation of remote learning caused a scramble across the country to prepare for online instruction, requiring flexibility and adaptation at the state, district, and school levels. In short succession, teachers received tutorials on using Zoom or other videoconferencing platforms, revised their curricula and standards for assessment, and developed printed packets to be distributed to students' homes, among other approaches to support the transition. Washington State developed resource lists for parents including courses, online resources and learning games, exercise activities, and downloadable content for learning (OSPI, 2020). 
Teachers soon found themselves taking on unprecedented responsibilities. Many states required or recommended regular teacher-student communication, such as through synchronous lessons, sometimes on a daily basis (as in Iowa, Minnesota, and Vermont), or on a weekly basis (as in Arkansas, Delaware, and Michigan) (Sparks, 2020). Schools switched to communications by email, phone calls and text messages, print, and even social media (Herold, 2020). A teacher in Greenville, South Carolina, remembered, "'It 'was just like a free-for-all. We [teachers] all went to school. We created lesson plans in, like, 12 hours. So 10 days of lesson plans in a day, essentially. And we had to be prepared to launch those lesson plans by Wednesday and to start doing full-on e-learning, which our kids had never really done before without us"" (Turner, et al., 2020). Florida schools relied on teachers to build new curriculum plans from a variety of sources, including Public Broadcasting System (PBS) programs, existing materials, and new materials developed on short notice (Kamenetz, 2020). This conversion was a monumental feat asked of teachers and administrators, which they rose to face in their combined commitment to students' wellbeing and education.

With the transition to remote learning, the focus on education provision shifted out of necessity, not just in terms of curricular material, but also in regard to other school roles and responsibilities. Many states, including Kansas, Wisconsin, and Virginia, prioritized preparations for graduating students to be able to complete their studies by waiving or allowing districts to request waivers for graduation requirements (Sawchuk, 2020; Sparks, 2020) that would no longer be feasible while conducting remote learning. Few states opted to specify the number of hours or methods used for remote learning (Sparks, 2020). In order to allow flexibility, Montana decided that remote learning did not have to be online, requiring no single mechanism for districts to continue education. Cleveland's long distance approach, recognizing that the district included a large high poverty population and many students had inconsistent or no internet and computer access, chose to prioritize review of material students had already been introduced to, instead of new curriculum material not yet covered during the year (Gewertz, 2020). Districts have also chosen to prioritize student social emotional welfare during the traumatic period. Schools play an important role not just in students' education, but also their wellbeing, and many districts have endeavored to continue providing these services, such as free meals, during the pandemic. The Salt Lake City (UT) School District, for example, provided breakfast and lunch Monday through Friday and dinners for students three days a week starting in April (Stauffer, 2020). These efforts highlight the flexibility required of schools and districts to address the specific needs of the students they serve and the importance of schools beyond the classroom.

The necessity for distance education and worries about equity led some larger urban districts to partner with local public television to develop programs for broadcast and online distribution. Los Angeles Unified School District partnered with Public Broadcasting System (PBS) stations across Southern California to produce educational programming for television, websites, and apps targeting PreK-second grade students, grades 3-8, and 9-12 (Kamenetz, 2020; Goldsmith, 2020; Li \& Lalani, 2020). Teachers were able also to turn to preexisting online curricula meeting multiple states' standards, 
including EngageNY, LearnZillion, and Open Up Resources (Rand, 2020). These partnerships have the potential to reach more students who may lack access to a laptop for joining online class sessions or regular internet access. Few of these programs have been studied systematically, so it is unclear how effective the programs selected are for meeting students' learning needs, however.

Some states and school districts have opted to reach their students through increased technology purchases, using existing budgetary funds or funding from the CARES Act grants. Chicago Public Schools reportedly gave out more than 100,000 devices to students (Turner et al., 2020), and Miami-Dade County Public Schools disseminated over 80,000 mobile devices and 11,000 smart phones to create Wi-Fi hotspots (Goldstein et al., 2020). The Greater Nashville (Tennessee) School District (Glover, 2020), put into place programs to purchase laptops or Wi-Fi hotspots for students who struggled with access to internet, though recent predictions cast doubt on whether the computers will be procured and distributed in time for the start of the new school year (Mangrum, 2020). With Cleveland's large high-poverty population, the district has attempted to distribute technology to enable access, but there are reportedly still many without regular access (Gewertz, 2020). Technology provision was not limited to major urban areas. Rural Minford, Ohio also attempted to deliver laptops and printed work to the roughly $25 \%$ of students without technology (Goldstein et al., 2020), and South Portland Maine Schools district began a one-to-one technology program in 2003, using both iPads for younger students and Chromebooks for older ones, and began pairing remote learning with online courses for teachers and administrators in the design and implementation of online learning (Hogan, 2020).

Some districts relied on previously obtained technology and information to reach those struggling with access. South Carolina (Munyan-Penney, 2020) and the Coachella Valley (CA) Unified District (Lee et al., 2020) both used previously purchased school buses with Wi-Fi hotspots, positioned primarily in lower-income neighborhoods, to enable greater Internet access. Idaho provided residents with a list of nocost or low-cost Internet options, while South Carolina developed maps showing Wi-Fi hotspots throughout the state, including those the state had placed on school buses. (Munyan-Penney, 2020). Lindsay (CA) Unified School District, with a large population of migrant agricultural workers, had started a community Wi-Fi project in 2016, allowing minimal interruptions to Internet access and learning as schools transitioned to remote learning (Kamenetz, 2020). Salem City, Virginia (VA) implemented a one-to-one program prior to 2020, providing Chromebooks to grade 3-12 students, paired with 200 hotspots and a partnership with a local cable company to provide free internet access for students qualifying for free and reduced lunch (Sawchuk, 2020). These approaches, both using newly purchased technology and previously appropriated technology distributed in new ways, became among the most popular means to address differential access to remote education offerings.

In the immediate aftermath of the closure of schools, districts wondered if and how they would continue to provide aid and services for students with disabilities, required under the Individuals with Disabilities Education Act (IDEA). Some even con- 
sidered not providing services out of a fear of compliance violations (Green, 2020). While the federal government granted waivers on grading and hours of class time, Secretary of Education Betsy DeVos rejected waivers on IDEA (Jordan, 2020; Green, 2020), and federal authorities have been flexible in the remote services (such as telehealth) that can be reimbursed through Medicaid, a major funding source for schoolbased health care (Jordan, 2020), enabling teachers and parents to find educational solutions. Special education teachers employed a variety of approaches to reach their students. Some connected with students virtually or via videotapes provided to parents demonstrating practices they can do with their children at home (Jordan, 2020). Many students with disabilities struggled to use online videoconferencing and learning tools or printed materials, requiring the assistance of human or technological aides such as screen-reading software, which are not included in programs such as Zoom (Hill, 2020). There is great variation in the population of students with disabilities, with many different needs and abilities, so for some the transition has been beneficial. The ASD Nest program in New York City focuses on incorporating students with autism into mainstream classrooms. Tracey Murray, a kindergarten teacher with ASD Nest, moved her classes, as well as a "social club" for students with autism (ASD), to practice conversations online, discovering that students found it easier to communicate and look each other in the eye when using Zoom instead of speaking in person (Hill, 2020). While states, districts, and teachers took drastic action to continue providing education to many students, the transition was not without problems, some of them more significant than others.

\section{Challenges and Inequities in Online Learning}

While many states and districts went to great lengths to continue educational services for students, the remote learning process was not without its challenges. The transition was not always smooth. Some districts and schools, particularly in urban areas, such as Sidwell Friends, a private school in Washington, D.C., which went paperless before 2020 (Turner, et al., 2020), more easily transitioned online because of existing infrastructure. But many school districts faced various issues, including lack of technology access for all students; teacher struggles to provide online lessons, student engagement, and the socioemotional impact of COVID-19 on students. Often, these issues corresponded more highly with preexisting conditions including family socioeconomic (SES) background, school funding and infrastructure, and student learning needs. Access to technology, and therefore, access to educational content during remote learning, proved to be a disproportionately greater challenge for students and families from lower socioeconomic statuses. US census data from 2015 suggested that $15 \%$ of US households lack high speed internet, which impacts students' ability to complete and turn in assignments; this is disproportionately more of an issue for Black teens than their peers (25\% compared to $4 \%$ of White teens and $6 \%$ of Latinx teens) (Anderson \& Perrin, 2020). Upon the initiation of social distancing and remote learning, adults working service industry jobs often lost their jobs, leading to a loss of stability for their families. One outcome of this could be the loss of internet access for their homes. Over 30 mil- 
lion jobs may have been lost during the months of March-May (Morath, 2020), hitting working class families the hardest, as these jobs are often ones which cannot be conducted remotely. Unable to pay bills, internet access could easily fall by the wayside, depriving their children of remote learning opportunities.

While many districts and states took or are in the process of taking steps to bridge the technology access gap as described in the previous section, a significant gap remains, which has a greater harm for those who need the most support. Rigorous remote learning, using online platforms and at least some synchronous learning, attendance tracking, and grading of students' work, was challenging to accomplish in the timeframe required, but implementation was skewed towards school districts with larger proportions of high-SES families. The policies and practices school districts reported following revealed that as few as $20 \%$ of schools may have offered rigorous remote learning nationwide (Lieberman, 2020), but this number is almost certainly worse in areas and schools that cater primarily to students from high poverty and minority backgrounds.

Teacher interactions and student access to remote learning both appeared to be significantly worse for students from disadvantaged backgrounds. By one estimate, up to $40 \%$ of the poorest students accessed remote learning just once a week (Kamenetz, 2020), while only $32 \%$ of teachers in high poverty districts reported interacting with students on a daily basis (compared to over 50\% in higher SES districts) (Education Week, May 7, 2020). In districts with few low-SES families, only $20 \%$ of school leaders were concerned with missing technology issues, while $68 \%$ of school leaders in districts with a high proportion of low-SES families were concerned with this issue (Herold, 2020). As described above, some states moved quickly to provide devices and hotspots to students lacking access, but for other states that made efforts to do this later in the semester or over the summer, technological options were more limited due to high demand (Herold, 2020; Munyan-Penney, 2020). The students in these states and districts are liable to then become even more behind should schools not reopen in the fall, as they will continue to miss out on class content and educational support. Some students were left out of state guidance and teacher efforts. While all states issued guidance on the provision of special education remotely, just two-thirds of states provided guidance or resources specifically for English learners (ELs) (Sparks, 2020). Due to the differential access to education, Jonathan Plucker of Johns Hopkins University Center for Talented Youth suggests that students may enter the Fall 2020 semester with a range of up to eight grade levels in knowledge (Bowman, 2020). This is a huge difference in experience during this challenging time, which, unless addressed, will have a disproportionately large impact on students from disadvantaged backgrounds.

Because of educational access and technological issues, teachers have struggled to make remote learning work effectively for all students while taking on a large workload themselves. Teachers reported struggling with learning to use the technology effectively. There have been reports of "Zoombombing," when outsiders join classroom Zoom sessions, shouting obscenities or otherwise disrupting the lesson (MunyanPenney, 2020). Some teachers struggled with learning how to host and manage live 
learning sessions and instead relied on recording sessions and sending out videos for students to watch on their own or on students completing assignments included in paper packets (Herold, 2020). Teachers, parents, and students agreed that teachers teaching online were far more likely to engage students than were videos or assignments to be done without teacher input, but many teachers found online teaching more difficult. In addition, teachers have also been asked to take part in additional professional development sessions to be able to maximize the effectiveness of remote learning, use of platforms such as Zoom, and how to support students during this time. While the professional development was necessary, requiring additional professional development created another strain on teachers' time and energy, when they too were dealing with trauma and stress in their own lives.

Some teachers were challenged to reach students over large distances. The Mountain Empire district (California) must provide services for students spanning more than 660 square miles, three Native American reservations, and six different communities (Sawchuk, 2020). Consequently, teachers are working longer hours than before. Rebecca Sorenson of rural Michigan reported holding individual Zoom sessions with students for 4-5 hours a day, followed by hours of driving to students' homes to drop off educational materials (Gewertz, 2020). Methods and requirements related to grading students' work quickly became an equity-focused conversation. Many districts thought that continuing to grade students punished low-income students without access to technology. This partly reflected school leaders' own ability to provide access to these students. High-poverty and rural district leaders reported that they were less able to provide remote learning options for all students than wealthy districts. Only $34 \%$ of high poverty districts reported able to provide access for all, compared with $62-73 \%$ for suburban and wealthier districts (Herold, 2020). Their concerns also were informed by student engagement in existing classroom activities. Almost one third (32\%) of students in districts of highest poverty families were not regularly logging into online classwork, completing assignments, or communicating with their teachers, while only $12 \%$ of highincome district students were "truant" (Herold, 2020). Districts subsequently considered moving to pass/fail grading systems (Sawchuk, 2020), focusing on moving students towards standards instead of to establish a grade, or passing all students already on track to progress to the next grade before the suspension of in-person learning (Schwartz, 2020). These approaches were intended to ameliorate the "double hit" of losing class learning time and school community (Fay, 2020) that are particularly beneficial to low income students.

In disadvantaged areas, the load of responsibility fell more significantly on parents to support their children's education. This challenge was greatest for younger students in elementary and pre-kindergarten (pre-K) grades, as well as students with disabilities, who require more supervision and support when using technology or completing classwork. Older students in secondary school, more self-sufficient and competent in technology use, did not generally require this level of supervision. Schools sought to coordinate more closely with the parents of students who appeared at risk of struggling or falling out of the system. Peter Kannam, principal at Henderson-Hopkins Elemen- 
tary/Middle School in Baltimore, Maryland, reported that their school hired four instructors to provide support for teachers to conduct online classes, send out daily text updates to parents on student engagement, as well as emails and robocalls two to three times per week, and held parent town halls every other week (Kannam, 2020). These efforts, coupled with laptop distribution to $80 \%$ of the students in need of them, appear to have paid off, as the school reported that almost $99 \%$ of their students were engaged in classes, with $84 \%$ attending classes over the first seven weeks of the pandemic school closure. But in some cases, these efforts could not replace the role of schools in engaging students and supporting their learning. "No amount of love and care at home can turn the average parent into a special-education teacher overnight. Nor can it enable them to practice occupational, speech, or physical therapy" (Hill, 2020).

Differences in student engagement can also be tied to the various roles schools play beyond the classroom. Students from low-SES families or experiencing homelessness rely on schools for food, healthcare, and social supports. Nearly 1.5 million students nationwide experience homelessness, while 13 million children experience hunger (Nuamah, et al., 2020). For these students, the supports schools provide are vital to their very survival. Even though schools have made efforts to provide meals, the food insecurity (Van Lancker \& Parolin, 2020) and socioemotional trauma that students are experiencing without school support systems are very real. These issues have been shown repeatedly by strongly designed research studies to have an impact on educational achievement.

Another factor that may have exacerbated differential implementation of remote learning is state education funding levels. Much has been written about the differently sized budgets maintained by public, private, and charter schools. Following the passage of the CARES Act, Secretary DeVos pushed for funds distributed by the federal government to states to be distributed increasingly to private schools (Stratford, 2020). This breaks from previous Title I funding standards, which restricted private schools to access these funds only for "equitable programs" (Jordan, 2020).

\section{Planning the Reopening of Schools}

As the rate of infection and death has decreased in some parts of the United States, thanks to social distancing and other preventative methods, attention has turned to planning the reopening of schools in the fall. All states and districts, however, are planning for a fall reopening. But with disease rates continuing at high levels, and even continuing to rise in many states as of late early July 2020, it is unclear when it will be safe to fully open. Many states began reopening public spaces and loosening public social distancing restrictions in May and June 2020, and subsequently are seeing an uptick in cases, in some contexts experiencing record highs in state COVID-19 cases. Should these renewed rising levels of COVID-19 prevalence continue into the fall, it is unknown if schools will be able to reopen as planned. While the American Association of Pediatrics (AAP) has recommended reopening in-person schooling on account of schools' role in child development (Kamenetz, 2020-e), the decision to do so belongs with state government and local school districts. Districts and states must determine if 
restarting in-person classes is worth the potential risk of infection, what steps and requirements to put in place, or if it is best to continue remote learning until infection rates diminish.

All US states are planning to reopen in the fall to some degree, working with school boards and state and local leaders to develop plans and guidance. The CDC has put forth a series of recommendations for school districts to consider enacting in the process of reopening, including social distancing inside the school building, enhanced cleaning of surfaces, and providing options for teachers who feel uneasy or are at greater risk of infection to work remotely (CDC, 2020). Given the potential for resurgence, others are preparing for a hybrid reopening approach or a return to remote learning even if schools reopen, purchasing more devices and considering one-to-one policies. Philadelphia School District is considering a hybrid plan based on limiting the number of students and staff in the school on a given day while allowing other students and staff to participate remotely based on health concerns (Hanna, 2020). Annette Anderson of the Johns Hopkins University Center for Safe and Healthy Schools sees this as the number one priority, "We need a one-to-one technology policy in every district... One student, one device with internet access included"" (Myers, 2020). Other dramatic restructuring ideas have been widely discussed, including two-session days, alternating school and home days to limit the number of students in a classroom (Sharfstein \& Morphew, 2020), "microschools" with intensive home-school cooperation, moving classrooms outdoors (Kamenetz, 2020), or extending the school year (Ehren \& Turkeli, 2020). Alternate-day plans have been widely adopted in other countries, and at least one large district, Fairfax, Virginia (Arnold, 2020), has announced such a plan. However, districts in Tucson (Arizona), Nashville (Tennessee), and Cincinnati (Ohio), have announced plans to fully open schools in the fall whenever it is safe, and allow each school to figure out how to implement social distancing (Conover, 2020; Mangrum, 2020; Ryle et al., 2020). These districts have also announced that parents will be allowed to keep their children at home and that any students remaining at home will be provided with remote learning for this purpose.

The most common approach to reopening being discussed as of this writing seems to be social distancing within the school building. The best methods to implement this practice include spacing students out within classrooms by separating individual desks, keeping students in small groups that do not mix with each other during the school day, keeping students out of common areas, and ending extracurricular sports and clubs (Sharfstein \& Morphew, 2020). Within-classroom spacing requires alternateday or two daily session strategies to reduce the number of students in each class. Some schools have considered repurposing cafeterias and shared space into additional classroom space (Editors, 2020), using barriers between desks, spacing out arrival and departure from schools (Sharfstein \& Morphew, 2020). Since many US students ride buses to and from school, social distancing on buses has been a widespread concern. School buses could, for instance, be run with fewer students, spaced out in each bus, with more buses, and with buses using certain routes to avoid mixing (Will, 2020). Fairfax (VA) County Public Schools (FCPS) developed diagrams for classroom desk arrangement, as 
well as seating in school buses. Based on a 77-seat bus, FCPS recommends 23 students per bus, as well as the bus driver's child and the driver (FCPS, 2020). These approaches are all intended to minimize transmission of the virus among students and staff.

But social distancing could be difficult to maintain, particularly for younger children and when students are not in organized environments such as classrooms. Distances are easy enough to maintain when students are stationary at their desks in a classroom, but time spent in the hallways moving between classes, in recess on the playground, and getting to and from school, are the bigger challenge areas, where social distancing protocols could easily break down without careful monitoring, a herculean task. This makes it clear that social distancing is not a silver bullet to enable schools to be reopened. There is some question about who should wear masks, at what ages students should start being required to wear them, and what procedures should be put in place for people to enter school buildings. The CDC recommends that students be encouraged, not required, to wear masks, and that all faculty and staff wear masks (Will, 2020) as so far, adults are the more at-risk population. While some countries have used temperature checks at the entrance of schools, some have seen this as an insufficient method given the possibility of transmission by individuals not displaying symptoms. Overreliance on temperature checks could give a "false sense of security" (Will, 2020), leading to the loosening of adherence to social distancing and mask wearing, to say nothing of potential complications when students must be checked following outdoor activities or fire drills. Other added steps could include testing, increased places to wash hands, and enhanced surface cleaning protocols. Dr. Anthony Fauci, director of the National Institute of Allergy and Infectious Diseases, recommended use of pooled testing (combining several students' tests together into one sample for testing) to save school resources and time (Watts, 2020).

Despite the existence of a number of different potential steps to address COVID-19 spread in schools, many teachers remain concerned about whether returning to schools is the right decision. Questions abound for what the classroom and school format will look like and how these policies will impact teachers' routines and procedures. School districts must consider how self-quarantine policies impact teacher sick leave, whether teachers can and should take on additional responsibilities regarding child safety and classroom sanitation, how to manage high-risk teachers (or teachers with family who are high-risk) (Will, 2020), to name a few issues. Parents too are concerned about what returning to school mean for their children. A survey of Los Angeles parents revealed that around $20 \%$ of parents are not yet ready for their children to go back to school in person (Blume, 2020). There is not much time left for states and districts to make these decisions, satisfy worried teachers (and parents), and implement policy changes or make physical changes to school grounds.

The changes necessary could also be cost prohibitive for some districts. At a time when state education budgets are facing cuts, school districts are estimated to need as much as \$1.8 million each (Will, 2020) for construction, repairs, changes to transportation protocols, new staff and health personnel, equipment, and maintenance. One common recommendation, an increase in school nursing personnel, is also potentially 
challenging for urban schools where nurses are spread across multiple locations, or rural areas, where qualified nurses may be hard to come by or attract. Even in California's affluent and mostly suburban Orange County, the ratio of nurse to students can range from 1:1,100 to 1:10,000 (Editors, 2020). A more practical and inexpensive alternative would be the hiring of "health aides," certified individuals who could assist schools with practical matters such as temperature checks, administration of prescription medicine, and distribution of masks, among other tasks. School health aides could also gather information, support the spread of information to a school's community, form relationships, and refer students to established health providers. These services would free up the time and responsibilities of school nurses (if present) to take on regular student health needs and more serious health concerns. Additional funding could come from the federal government. The House of Representatives passed a bill, the Health and Economic Recovery Omnibus Emergency Solutions (HEROES) Act in April 2020, which would have included additional education funds, but it has not been introduced to the Senate. The funds could be prioritized for public school districts facing the greatest levels of COVID-19-related learning and staffing loss (Sharfstein \& Morphew, 2020).

While these steps may support schools in putting into place health protocols to minimize spread of COVID-19, they do little to address the learning gaps that have developed between students with and without regular access to remote learning. How should schools go about bridging the potentially eight levels of difference between students that have developed over one semester? One potentially effective approach to address this gap could be tutoring. One on one or small group tutoring support has been proven to have a strong effect on learning reading and mathematics. Some existing tutoring programs consistently produce effect sizes of 0.40 or more, around 5 additional months of learning (Slavin, 2020), and tutoring by paraprofessionals has been shown to be as effective as tutoring administered by teachers (Inns et al., 2018). In large enough numbers, tutors, perhaps recruited and organized through AmeriCorps, could move the needle for students to make up the COVID-19 learning loss slide. The government of the Netherlands recently set aside \$278 million to provide support to all students in elementary, secondary, and vocational schools who need it (Baars, 2020), while the UK set aside roughly $\$ 1.24$ billion for tutoring and other services (Adams, 2020). Were the US to implement a similar program, considering the different population size, similar approaches could cost \$5-7.5 billion (Slavin, 2020). Regardless of the methods used, significant steps must be taken to address the widening gap in learning brought on by the pandemic.

\section{Implications}

In contrast to the transition to remote learning that occurred in more centralized educational systems, such as South Korea, the United States has a long way to go to address the challenges of equity in the implementation of remote learning. While some steps and school-network-platform partnerships made efforts to close the gaps, a large portion of students experienced lower access to and participation in education after the initiation of remote learning. Reopening schools to in-person instruction would enable great- 
er access to education, but comes with its own questions, including whether families would be comfortable sending their children back to schools, whether teachers would risk exposure, what steps should be taken to limit transmission of the virus and how best to ensure compliance with these protocols, and how school districts would pay for any changes at a time when school budgets are being cut. Regardless of whether schools reopen, remote learning is continued, or some sort of hybrid of in-person and online learning is implemented in the fall, the largest question of all remains: how can schools close the gap that has formed due to the COVID-19 slide and unequal access to education during the spring semester? The federal government and US states must consider the steps taken by other countries as they reopen to learn what is most effective, how challenges can best be addressed as they arise, and what programs, such as widescale tutoring provision, can make up for the time lost.

\section{References}

Adams, R. (2020, June 18) English schools to get $£ 1$ bn to help pupils catch up after lockdown. The Guardian. https://www.theguardian.com/education/2 020/jun/19/english-schools-to-get-1bn-tohelp-pupils-catch-up-after-lockdown

Anderson, M., \& Perrin, A. (2018, October 26) Nearly one-in-five teens can't always finish their homework because of the digital divide. Pew Research Center. Retrieved June 18, 2020, from https://www.pewresearch.org/facttank/2018/10/26/nearly-one-in-five-teenscant-always-finish-their-homeworkbecause-of-the-digital-divide/

Arnold, J. (2020, June 16) Fairfax County parents, teachers question feasibility of plan to reopen schools. Wusa9.Com. https://www.wusa9.com/article/news/educ ation/fairfax-county-parents-teachersquestion-reopening-plan/65-1e59e898ac29-4719-9944-be8055c46e65

Baars, L. van. (2020, June 3) Op het Willem de Zwijger College mag een kwart van de klas weer naar school: 'Wel chill om mensen weer te zien.' Trouw. https://www.trouw.nl/gs-bdded0e9

Baker, M. (2020, May 15) When did the coronavirus arrive in the U.S.? here's a review of the evidence. The New York Times.

https://www.nytimes.com/2020/05/15/us/ coronavirus-first-case-snohomishantibodies.html

Binkley, C. (2020, February 28) US schools start planning for possible spread of coronavirus. KUTV.

https://kutv.com/news/nation-world/usschools-start-planning-for-possiblespread-of-coronavirus-02-28-2020160129388

Blume, H. (2020, June 29) L.A. schools reopening: Many parents, teachers are not ready. The Los Angeles Times. https://www.latimes.com/california/story/ 2020-06-29/school-reopening-losangeles-campus-employees-parents

Bowman, K. (2020, June 9) School closures prompted by COVID-19 could amplify knowledge gaps. The Hub. https://hub.jhu.edu/2020/06/09/school- 
Storey \& Slavin. The US Educational Response to the COVID-19 Pandemic.

closures-worsen-knowledge-gaps-inpublic-school-classrooms/

Conover, C. (2020, June 29) TUSD reopening plan adds money, space in hopes of mitigating COVID-19. Retrieved June 30, 2020, from https://www.azpm.org/p/home-articlesnews/2020/6/29/175635-tusd-reopeningplan-adds-money-space-in-hopes-ofmitigating-covid-19/

Editor. (2020, June 15) "Hybrid learning" to be new normal as California schools reopen. Times of San Diego. https://timesofsandiego.com/education/20 20/06/14/hybrid-learning-to-be-newnormal-as-california-schools-reopen/

Ehren, M., \& Turkeli, R. (2020, June 13) How to repair learning loss from school closures during COVID-19 pandemic: Which interventions and programmes are effective? VU Learn. Retrieved June 17, 2020, from https://www.researchinstitutelearn.nl/en/p rofessionals-en/how-to-repair-learningloss-from-school-closures-during-covid19-pandemic-which-interventions-andprogrammes-are-effective/

FCPS. (2020) Reopening schools plan-Inperson instruction with social distancing | Fairfax County Public Schools. https://www.fcps.edu/returnschool/reopening-schools-plan-completeinformation/school-learning-health-andsocial

Forgie, A. (2020, April 14) Timeline: How Utah's school closure dominoes fell. KUTV. Retrieved June 14, 2020, from https://kutv.com/news/coronavirus/timelin e-how-utahs-school-closure-dominoes-fell

Gewertz, C. (2020, June 10) Instruction during COVID-19: less learning time drives fears of academic erosion. Education Week. http://www.edweek.org/ew/articles/2020/ 05/27/instruction-during-covid-19-lesslearning-time-drives.html?cmp=eml-enleunews $1 \& M=59584475 \& U=21229 \&$ UUID $=e 439066377 \mathrm{e} 0 \mathrm{~b} 72993 \mathrm{ab} 736700 \mathrm{e} 944 \mathrm{e} 7$

Goldsmith, J., \& Goldsmith, J. (2020, March 14) PBS steps in with educational pro- gramming as Los Angeles schools close. Deadline. https://deadline.com/2020/03/pbs-socalkcet-lausd-los-angeles-schools-close1202883111/

Goldstein, D., Popescu, A., \& Hannah-Jones, N. (2020, April 6) As school moves online, many students stay logged out. The New York Times. https://www.nytimes.com/2020/04/06/us/ coronavirus-schools-attendanceabsent.html

Green, E. L. (2020, April 28) DeVos decides against special education waivers during the pandemic. The New York Times. https://www.nytimes.com/2020/04/28/us/ politics/coronavirus-devos-specialeducation.html

Hanna, M. (2020, June 15) Philly eyes school reopening plan that would stagger when students and staff come to schools. The Philadelphia Inquirer. https://www.inquirer.com/health/coronavi rus/philadelphia-schools-reopeningsurvey-coronavirus-online-learning20200615.html

Herold, B. (2020, April 29) The disparities in distance learning under coronavirus (in charts). Education Week. http://www.edweek.org/ew/articles/2020/ 04/10/the-disparities-in-remote-learningunder-coronavirus.html

Hill, F. (2020, April 18) The pandemic is a crisis for students with special needs. The Atlantic.

https://www.theatlantic.com/education/arc hive/2020/04/special-education-goesremote-covid-19-pandemic/610231/

Hogan, K. (2020, June 16) Whatever it takes: How this district pivoted with the pandemic. ESchool News. https://www.eschoolnews.com/2020/06/1 6/whatever-it-takes-pandemic/

Inns, A., Lake, C., Pellegrini, M., \& Slavin, R. (2018) Effective programs for struggling readers: A best-evidence synthesis. Paper presented at the annual meeting of the Society for Research on Educational Effectiveness, Washington, DC.

Jones, C., \& Pflaum, N. (2020, March 24)

State moves to keep Utah schools funded 
Storey \& Slavin. The US Educational Response to the COVID-19 Pandemic.

during pandemic. KUTV.

https://kutv.com/news/beyond-the-

books/state-moves-to-keep-utah-schools-

funded-during-pandemic

Jordan, P. (2020, June 10-a) Attendance playbook: Reducing chronic absenteeism. FutureEd. Retrieved June 13, 2020, from https://www.future-ed.org/attendanceplaybook/

Jordan, P. (2020, June 10-b) What Congressional COVID funding means for K-12 schools. FutureEd. Retrieved June 13, 2020, from https://www.futureed.org/what-congressional-covid-fundingmeans-for-k-12-schools/

Kamenetz, A. (2020, June 17) 5 Radical schooling ideas for an uncertain fall and beyond. NPR.Org. Retrieved June 17, 2020, from https://www.npr.org/2020/06/17/8782058 53/5-radical-schooling-ideas-for-anuncertain-fall-and-beyond

Kamenetz, A. (2020, May 27) Survey shows big distance learning gaps for low-income and special needs children. NPR.Org. Retrieved June 18, 2020, from

https://www.npr.org/sections/coronaviruslive-

updates/2020/05/27/862705225/surveyshows-big-remote-learning-gaps-for-lowincome-and-special-needs-children

Kamenetz, A. (2020, March 26) The biggest distance-learning experiment in history: Week One. NPR.Org. Retrieved June 15, 2020, from

https://www.npr.org/2020/03/26/8219215

75/the-biggest-distance-learningexperiment-in-history-week-one

Kamenetz, A. (2020, June 29) U.S. pediatricians call for in-person school this fall.

NPR.Org.

https://www.npr.org/sections/coronaviruslive-updates/2020/06/29/884638999/u-spediatricians-call-for-in-person-schoolthis-fall

Kannam, P. (2020, June 22) Lost learning during Covid-19: Understanding which students lost the most" at 4-5 PM EDT today. [Webinar]

Retrieved from https://bioethics.jhu.edu/events/lost- learning-during-covid-19-understandingwhich-students-lost-the-most/

Kirsch, Z. (2020, May 6) As COVID-19 keeps most schools shuttered for the rest of the year, a growing number in Wyoming and Montana partially reopen. Retrieved June 14, 2020, from https://www.the74million.org/article/ascovid-keeps-most-schools-shuttered-forthe-rest-of-the-year-a-growing-numberin-wyoming-and-montana-partiallyreopen/

Lee, C., Goss, J., \& Gao, N. (2019, April 25) How California's digital divide affects students. Public Policy Institute of California. https://www.ppic.org/blog/howcalifornias-digital-divide-affects-students/

Li, C., \& Lalani, F. (2020, April 29) The COVID-19 pandemic has changed education forever. This is how. World Economic Forum. Retrieved June 15, 2020, from https://www.weforum.org/agenda/2020/0 4/coronavirus-education-global-covid19online-digital-learning/

Lieberman, M. (2020, June 15) Only one in five schools offered "rigorous" distance learning, study says. Education Week. Retrieved June 17, 2020, from http://blogs.edweek.org/edweek/DigitalEd ucation/2020/06/remote_learning_achieve ment_gap.html?cmp=SOC-SHR-FB

Mangrum, M. (2020, June 24) Nashville families want remote options when classes resume, MNPS director says. The Tennessean.

https://www.tennessean.com/story/news/e ducation/2020/06/23/metro-nashvilleschools-director-update-schoolreopening-planscoronavirus/3235619001/

Map: Coronavirus and School Closures (2020, March 6) Education Week. Retrieved June 24, 2020 from https://www.edweek.org/ew/section/multi media/map-coronavirus-and-schoolclosures.html

Meltzer, E. (2020, April 22) Amid extended school closure, Colorado to allow smallgroup instruction in some districts. Chalkbeat Colorado. https://co.chalkbeat.org/2020/4/22/212321 
Storey \& Slavin. The US Educational Response to the COVID-19 Pandemic.

51/colorado-coronavirus-school-closureclasssroom-instruction

Morath, E. (2020, June 3) How many U.S. workers have lost jobs during coronavirus pandemic? there are several ways to count. Wall Street Journal.

https://www.wsj.com/articles/how-manyu-s-workers-have-lost-jobs-duringcoronavirus-pandemic-there-are-severalways-to-count-11591176601

Munyan-Penney, N. (2020, April 17) Distance learning in the time of COVID 19. Education Reform Now.

https://edreformnow.org/blog/distancelearning-in-the-time-of-covid-19/

Nagel, D. (2020, May 11) Updated list of statewide school closures with closure dates. THE Journal. https://thejournal.com/articles/2020/03/17 /list-of-states-shutting-down-all-theirschools-grows-to-36.aspx

Nuamah, S., Good, R., Bierbaum, A., \& Simon, E. (2020) School closures always hurt. they hurt even more now. Education Week. https://www-edweekorg.proxy1.library.jhu.edu/ew/articles/202 0/06/09/school-closures-always-hurt-theyhurt-even.html?cmp=eml-enl-eunews $2 \& \mathrm{M}=5 \% \mathrm{E} 2 \% 80 \% \mathrm{~A} 6$

RAND. (2020, April 2) Schools pivot online in wake of COVID-19: Q\&A with RAND experts. Q\&A (The RAND Blog). https://www.rand.org/blog/2020/04/schoo 1s-pivot-online-in-wake-of-covid-19qampa-with.html

Ritchie, H., Ortiz-Ospina, E., Beltekian, D., Mathieu, E., Hasell, J., Macdonald, B., Giattino, C., \& Roser, M. (2020) Coronavirus Pandemic (COVID-19). Our World in Data.

https://ourworldindata.org/coronavirus/co untry/united-states

Ryle, J., Richard, R., \& WCPO staff. (2020, June 29) Cincinnati Public Schools Board of Education approves blended back-toschool plan. WCPO.

https://www.wcpo.com/news/localnews/cincinnati-public-schools-board-ofeducation-weighing-pros-and-cons-ofproposed-back-to-school-plans
Sawchuk, S. (2020, April 1) Grading students during the coronavirus crisis: what's the right call? Education Week. http://www.edweek.org/ew/articles/2020/ 04/01/grading-students-during-thecoronavirus-crisis-whats.html

Schwartz, S. (2020, May 13) States all over the map on distance learning rigor, detail. Education Week.

http://www.edweek.org/ew/articles/2020/ 05/13/enormous-variation-among-stateonline-learning-programs.html

Sharfstein, J. M., \& Morphew, C. C. (2020) The urgency and challenge of opening $\mathrm{K}$ 12 schools in the fall of 2020. JAMA. https://doi.org/10.1001/jama.2020.10175

Slavin, R. (2020, April 23) A Marshall Plan for post-COVID-19 recovery. Robert Slavin's Blog. https://robertslavinsblog.wordpress.com/2 020/04/23/a-marshall-plan-for-post-covid19-recovery/

Sparks, S. D. (2020, June 8) Schools were crowded before COVID-19. after, educators say it will be worse. Education Week. Retrieved June 13, 2020, from http://blogs.edweek.org/edweek/insideschoolre-

search/2020/06/teacher_principals_district s_extremely_crowded_social_distancing. $\mathrm{html}$ ?cmp=SOC-SHR-FB

Sparks, S. D. (2020, March 30) The lost senior year: Credits, proms, sports all in jeopardy. Education Week. http://www.edweek.org/ew/articles/2020/ 03/30/the-lost-senior-year-credits-promssports.html

Stauffer, M. (2020, April 1) How Utah kids can get free dinner 3 times a week, plus breakfast and lunch. KUTV. https://kutv.com/news/local/how-utahkids-can-get-free-dinner-3-times-a-weekplus-breakfast-and-lunch

Stratford, M. (2020, May 26) DeVos vows new regulation on relief aid for private school students. POLITICO. Retrieved June 14, 2020, from https://politi.co/2yDSFle

Strauss, V. (2020, June 19) Georgia becomes first state to seek suspension of standard- 
Storey \& Slavin. The US Educational Response to the COVID-19 Pandemic.

ized tests in 2020-21. Washington Post. https://www.washingtonpost.com/

Turner, C. (2020, June 10) Senate panel asks: when can K-12 schools safely reopen? NPR.Org. Retrieved June 13, 2020, from https://www.npr.org/sections/coronaviruslive-

updates/2020/06/10/874049532/senatepanel-asks-when-can-k-12-schools-safelyreopen

Turner, C., Adame, D., \& Nadworny, E. (2020, April 11) "There's a huge disparity": what teaching looks like during coronavirus. NPR.Org. Retrieved June 19, 2020, from https://www.npr.org/2020/04/11/8308561 40/teaching-without-schools-grief-then-afree-for-all

Watts, A. (2020, June 30) Pool testing at schools may be helpful for reopening, Fauci says. CNN. Retrieved June 30, 2020, from https://www.cnn.com/politics/livenews/covid-19-school-work-reopeningtestimony-06-30-20/index.html

Will, M. (2020a, June 10) How schools in other countries have reopened. Education Week. https://www-edweekorg.proxy1.library.jhu.edu/ew/articles/202 0/06/11/how-schools-in-other-countrieshave-reopened.html

Will, M. (2020b, June 10) Managing buses may be the hardest part of reopening schools. Education Week. https://wwwedweek-

org.proxy1.library.jhu.edu/ew/articles/202 0/06/11/managing-buses-may-be-thehardest-part.html

Will, M. (2020c, June 10) The socially distanced school day. Education Week. https://www.edweek.org/ew/issues/reopen ing-schools/the-socially-distanced-schoolday.html?cmp=SOC-SHR-FB

Will, M. (2020d, June 10) What needs to change inside school buildings before they reopen. Education Week.

https://www-edweek-

org.proxy1.library.jhu.edu/ew/articles/202 0/06/11/what-needs-to-change-insideschool-buildings.html

Will, M. (2020, June 11) Keeping students and staff healthy and safe when schools reopen. Education Week.

http://www.edweek.org/ew/articles/2020/ 06/11/keeping-students-and-staff-healthyand-safe.html?cmp=soc-edit-tw

Will, M. (2020, June 30) As schools plan for reopening, worried teachers say they have more questions than answers. Education Week - Teaching Now. Retrieved July 1, 2020, from

http://blogs.edweek.org/teachers/teaching _now/2020/06/schools_plan_how_to_reo pen_teachers_unanswered_questions.html ?cmp=SOC-SHR-FB. 